\title{
Research on the development of green buildings under the high-speed development mode
}

\author{
Shihan Zhu ${ }^{1}$, Jingjing Liu ${ }^{1,2 *}$ and Chenjie $\mathrm{Wu}^{1}$ \\ ${ }^{1}$ School of Civil Engineering and Architecture, Wuhan Polytechnic University, China \\ ${ }^{2}$ No. xsky2021146, Wuhan Polytechnic University, China
}

\begin{abstract}
In the rapid development of science and technology today, environmental problems are becoming more and more serious; the construction industry as the first high energy-consuming field with human production and life, the promotion of green buildings is of great significance. Under the high-speed development mode, how to make green buildings develop steadily has become a problem to be solved by various industries in China. Through the literature research method and the social investigation method, this paper analyses the development constraints of green buildings from the perspective of the four participants of market economy: government, real estate enterprises, consumers and practitioners. Respectively put forward some suggestions such as policy regulation, enterprise norms, green talents cultivation and collect feedback.
\end{abstract}

\section{Introduction}

The green buildings in the public's cognition are colorful, surrounded by flowers and plants, full of the atmosphere of nature. In fact, the purpose of proposing green buildings is to save energy, such as the famous green building, the "Crystal Building" at London's West Gate, which collects and uses solar energy to save $50 \%$ of electricity and reduce $\mathrm{CO} 2$ emissions by $65 \%$ compared to similar office buildings.

The green building boom first originated in the 1970s. The shortage of oil resources has caused panic and led to a global campaign for energy-efficient design in the construction community. Architecture, as a bridge between man and nature, is itself a kind of destruction of the earth's ecological environment. The ultimate prospect of green building is to run the concept of lowcarbon environmental protection, energy saving and emission reduction through the whole process of project planning and design, architectural design, building materials selection, construction plan to selection and post-operation maintenance, and to minimize the damage to the ecological environment.

\section{Overseas and Domestic Research Status of green building construction and development}

\subsection{The current state of green building development in China}

In 2019 , the country has built more than 5 billion square meters of green building area, in 2019 the proportion of new urban construction, green buildings accounted for $65 \%$. In the same year, China's Ministry of Housing and Urban-Rural Development officially issued the new national standard Green Building Evaluation Standard GB/T50378-2019, effective August 1, 2019. The original Green Building Evaluation Standard GB/T 50378-2014 was repealed at the same time, and the changes of the scoring system are shown in Figure 1.

In February 2021, the State Council issued the Guidance on Accelerating the Establishment and Improvement of a Green Low-Carbon Cycle Development Economy. It clearly states that "green community creation initiatives are under way to develop green buildings".

At present, the promotion and development of green buildings in China is still in its infancy in the pilot development stage. China's green building development depends on government guidance and support, consumers; enterprises are more passive acceptance, lack of market initiative. 


\begin{tabular}{ll}
\hline Land saving and outdoor environment & Safety and Durability \\
Energy saving and energy utilization & Healthy and Comfort \\
Water saving and water resource utilization & Convenience of Occupation \\
Material saving and material resource utilization & $\begin{array}{l}\text { Resources Conservation } \\
\text { Environmental Livability }\end{array}$ \\
$\begin{array}{l}\text { Opdoor environment quality } \\
\text { Construction management }\end{array}$ & \\
\hline
\end{tabular}

from "Green Building Evaluation Standard" GB/T50378-2014 from the third edition for examination and approval of the manuscript of the new national standard "Green Building Evaluation Standard" GB/T50378-2019

Figure 1.In 2019 China's new green building_ the change of the scoring system

The changes and influences: (1) There is still no divided according to each professional provisions chapter; (2) Section number changed from 138 to 107 , but chapter classification and provision more integration; (3) For various professional and all kinds of work involved in the role of requirements will be higher.

\subsection{Take the United States as an example to see the development of green buildings abroad}

The United States was one of the first countries to start developing green buildings, and the LEED standard in the United States is also one of the highest-recognized green evaluation standards. Since the 1990s, the United States from the federal government to local governments around the development of green building industry goals issued a large number of policies and regulations and preferential strategies, with its strong scientific research and economic strength, vigorously develop new and renewable energy sources, hoping to obtain new economic growth points.

The U.S. government authorizes the Green Building Commission to focus on four areas of market development in the green building industry: first, the development of green buildings, climate change; Second, sustainable cities and communities; Third, green affordable housing; To this end, the U.S. Green Building Council's strategies for driving market development are:(1) through demonstration guidance, (2) promoting incentives for guides, and (3) raising the minimum requirements for all buildings.

The policy design and strategic measures of green building in the United States have played a great role in promoting the transformation of industry and market, which have great enlightenment and learning effect on the development of green buildings in China.

\section{The difficulties in the promotion of green buildings under the high-speed development mode}

Since China's reform and opening-up, China's green economy has started relatively late because the country has focused on economic development, neglected environmental protection, and failed to pay sufficient attention to the green economy.

Although the development strategies of various countries have been studied, there is still a lack of experience and green building development methods with their own characteristics. The following will be combined with China's economy system, from the market economy participants to carry out a constraint analysis, focusing on the promotion of difficulties.

\subsection{Government policy is not perfect}

Through the macro-control of the country, the market supply and demand relationship can follow the law of value. In recent years, the Ministry of Housing and Construction and other organs have also promulgated incentives with green buildings, but the mandatory policy is highly targeted. But it lacks flexibility, for example, with 4,246 green building design signs from the 2016 survey, but only 269 running logos.

Although the green building has been vigorously promoted by the government, but its promotion results are not very ideal. Green buildings have not established a market supply and demand-led operating mechanism. Compared with traditional buildings, investment risks, investment recovery period and investment costs of green buildings are higher, so that it is not favoured by developers. And fundamentally, green buildings promote regional energy conservation and emission reduction, and the positive impact on the residential environment and other long-term value has not been paid attention to in policy, as a result, it cannot cause developers and owners to pay attention to, so that green buildings flow in the surface floating in the cloud.

\subsection{Real estate development enterprises are not motivated enough to promote green buildings}

For real estate development enterprises, real estate construction is to obtain benefits. Whether or not to 
invest in green buildings depends on whether green buildings can bring them more economic benefits. Under the current high-speed development mode in China, the cost of building green buildings and the needs of consumers may not be able to make up for the investment of a large number of private enterprises, especially the expansion of early investment in a short period of time cannot be recovered, so that the investment recovery period, cash flow correction time extended and the risk increases. [1] From another point of view, under the influence of the planned economic system, the management decision-making level of enterprises does not know enough about green buildings.

The negative attitude towards the concept of green building, which has aroused the whole company and the whole industry has limited its scale expansion and the widespread implementation of the concept.

The downturn in the green construction industry is also related to the economic downturn in recent years. In particular, the new corona pneumonia outbreak has hit the global economy hard by 2020. China is the only major economy in the world to achieve positive economic growth in 2020 with an economic growth rate of $2.3 \%$, but still down 3.7 percentage points from 2019 . At present, China's real estate demand has declined slightly. Under the government's macro-control, land and housing development investment growth rate will slow down accordingly. At the same time, it will also directly affect the enterprise's investment in green buildings.

\subsection{Consumers lack "green perceptuality"}

At present, most green buildings on the market because of the use of new technology and other reasons lead to higher prices, and consumers when buying real estate more consideration is mainly household type, location, price, transportation, supporting factors, the concept of green buildings in China has not been widely implemented, even consumers using green buildings, the understanding of green buildings is very limited, do not realize that the benefits of green buildings for them is hidden and sustainable. Consumers do not get a better living and living experience, the convenience and low prices are relatively more intuitive, so they are reluctant to spend higher prices to pay for green buildings [2].

At the same time, there are gaps in the operation and post-maintenance of green buildings. By the end of 2018, there were more than 13,000 projects in China that had obtained green building evaluation labels, specifically, and the number of operational identification projects accounted for only about $6 \%$ of the total number of identified projects. Although there are many studies on the evaluation standards and technological breakthroughs of green buildings, there are very few follow-up satisfaction evaluations for consumers. Consumers lack "perceivability" of green buildings, and household satisfaction is inadequate, which in turn cannot contribute to the market.

\subsection{Technology and design have limitations}

The design of green buildings focuses on image and neglects their essence. Many architects in the construction of green buildings, in order to novelty and creativity, blind pursuit of landmark buildings, etc. without local conditions to consider the adaptability of green buildings, development performance cannot meet people's practical standards, but caused a huge waste of financial resources, material resources, human resources, space and energy [3]. In addition, most skilled workers, although highly skilled means, but the level of education is not high, the acceptance of new things is not high, and the construction of green building technology than traditional buildings more complex to the level of education and professionalism also have certain requirements. Therefore, the green construction industry labor resources are scarce, if blindly promote green buildings, not only to the green building itself is not conducive to the entire construction industry labor market will also bring a greater impact.

\section{4 the future development of green buildings with Chinese characteristics}

\subsection{Stablish a sound reward and punishment and evaluation mechanism to promote the development of green buildings}

The incentive policy of green building is an important factor to promote its development, the characteristics of China's economic system should be brought into play, and the government should act as the "guide" in the implementation of green building. The construction cost of green building is higher than that of traditional building, and certain incentives can compensate for its cost and stimulate the development market. Based on the current situation of the industry, China's green building evaluation standards should be implemented throughout the life of the building. Increase user research, regular testing, regular survey of the surrounding environment and other means to enable green buildings to maximize its value. Reward and punishment mechanism should complement each other, adopt the "long-term reward and punishment" "enterprise responsibility system" approach, to reward outstanding construction enterprises, if the follow-up work of the enterprise is not guaranteed to recover the reward or punishment and other means. Stimulate the development of the market, ensure product quality, improve public awareness, improve the relationship between supply and demand, that is, promote the development of green buildings [4].

\subsection{Enterprises correctly recognize "green benefits" and enhance social responsibility}

If green buildings can bring high returns, the incremental benefits are greater than the incremental costs, and enterprises will choose to develop green buildings. In contrast to traditional buildings, "green income" includes 
not only tangible increases in cash profits (e.g., green certification, companies receive policy subsidies), but also increased developer reputation and brand value. Among them, the benefits of the latter mainly come from the positive effects of green construction projects on the environment and society, which is consistent with the development concept of China's high-speed development mode, and the results are shown in Figure 2.

Project from construction to completion and production, for real estate development enterprises, the main revenue concentrated in the sales period. In the sales process, real estate development enterprises can carry out key publicity on the concept of green housing, design, technology, including the organization of trial housing experience, so that consumers realize that green buildings in terms of saving resources can bring direct economic benefits. For example, solar water heaters can save electricity while providing hot water without interruption, water treatment system to recycle wastewater into water, wastewater utilization rate can reach $40 \%$ to $60 \%$. These benefits will help enterprises to win the recognition and trust of consumers, its wordof-mouth effect is much greater than any period of advertising, and can be effectively accumulated over the long term.

At the same time, enterprises also need to enhance their sense of social responsibility. They cannot blindly pursue the maximization of benefits. Like education and training on energy conservation and environmental protection can be carried out on a regular basis, and the implementation of national policies can be actively cooperated with the implementation of national green concepts to contribute to a force.

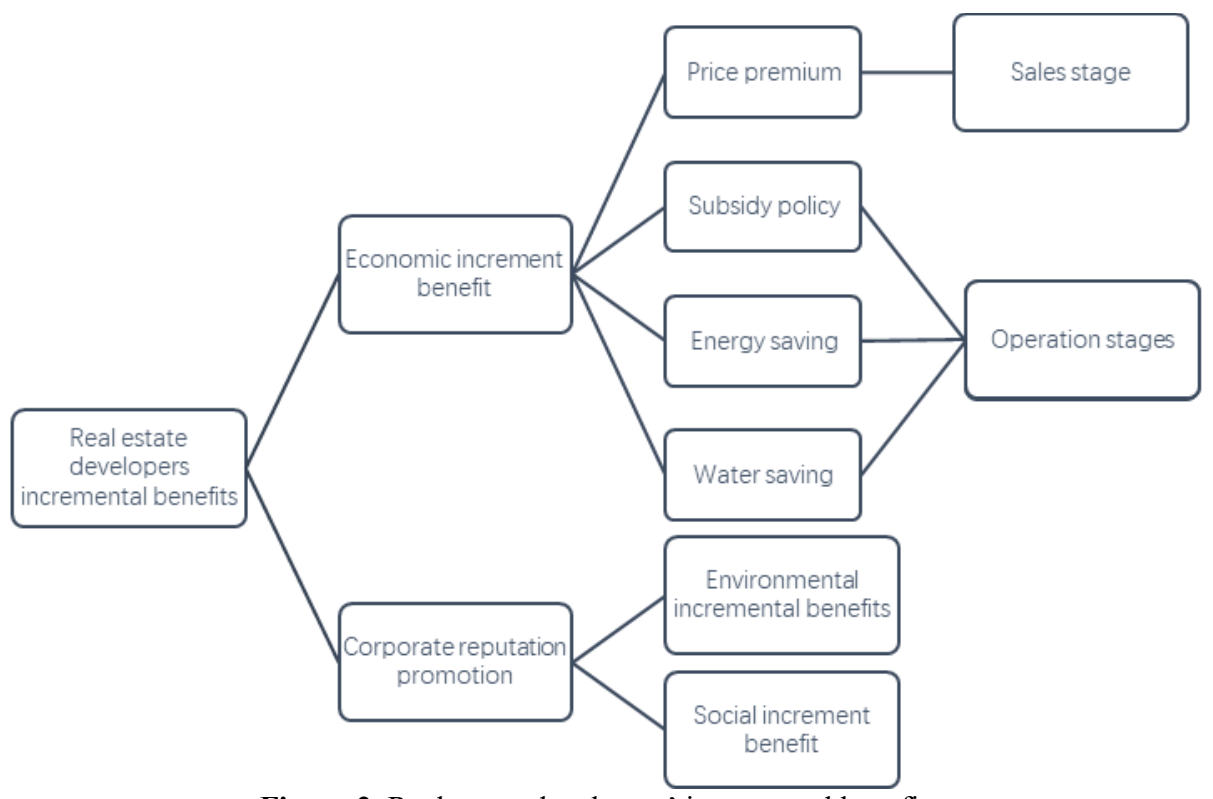

Figure 2. Real estate developers' incremental benefits

\subsection{Develop education for green building technicians}

Green building for the development direction of the construction industry, and the problem of talent shortage for the green building market cannot be ignored, green building-related occupations in China's construction market belongs to the emerging occupation, requiring technical personnel not only have the professional skills of traditional architecture, but also need to integrate new energy and ecological knowledge. China can learn from the training experience of foreign green building talents, more in various technical-related institutions of higher learning and technical colleges to carry out professional courses, systematic training of design, construction, management and other aspects of technical personnel, to ensure that the green construction industry labour market talent reserves. For the existing traditional construction personnel, to solve the shortage of talent and achieve a gradual transformation of technology, related companies can select some technical personnel sub-professional, phased learning green building expertise, and then" one to one, one to two" and other methods to help other workers.

\subsection{Fill the gap in the market and promote the positive cycle of the green building market}

In addition to government regulation and corporate selfregulation, public awareness and feedback gathering is also essential. At present, China lacks the evaluation criteria for household satisfaction; many enterprises drill policy loopholes, for "green" and "green", resulting in false declarations and even waste of resources phenomenon. The establishment of household satisfaction evaluation standards for consumers to provide a strong and powerful backing, which is conducive to the standardization of enterprises. At the same time, through satisfaction surveys such as the establishment of household surveys, comparison of building energy conservation, not only to make the public more understanding of green buildings, and truly realize that investment in green buildings to obtain a healthy and comfortable living experience are entirely 
worthy, and play a role in publicity to attract more consumers to choose to buy green buildings.

In the concrete implementation, it must to be open and transparent for green buildings from the design, construction, sales, operation, maintenance of a series of evaluation standards, so that consumers have confidence in the green building market. In some key technologies, such as the market already existing solar, wind energy, wastewater treatment, wall environmental protection materials, it need establish consumer recognition, even they have a preference of green materials [5]. From the consumer's point of view, find the problem and solve the problem. Consumer demand is responsive and the future focus of green building development can also be revealed, so that the entire green building market remains highly active positive cycle.

\section{Conclusion}

Green building is just a green concept. Countries have different names for green buildings, for example, green buildings in Japan are called environmental symbiotic buildings, and in Europe or the United States are called ecological buildings, sustainable buildings or energyefficient buildings. No matter what name, which evaluation criteria, it expresses the world's unified attitude to encourage the development of green buildings. The green concept is the basic premise of realizing the harmonious and simultaneous development of nature and economy, and it is also the only means for mankind to deal with the energy crisis and the difficult problem of survival.

The energy crisis is relevant to every industry and everyone. Construction industry as a major energy consumption industry, to achieve green industry reform is not overnight. Reform requires efforts of each generation. How to develop green architecture with high quality is a complex problem, comprehensive the above analysis and the suggestion is still partial. China as the world's largest socialist country urgently needs to find out a way of high-speed development mode of green buildings with Chinese characteristics, which requires more experts inside course of study for further analysis and research.

\section{Acknowledgments}

The research is supported by the Undergraduate Research Project under Grant No. xsky2021146 of Wuhan Polytechnic University: The development status and future trend of green buildings in China and international.

\section{References}

1. Shi Yong, Analysis of the economics of green building based on the perspective of real estate development enterprises -- take a project as an example[D]. Shandong University of Architecture, 2020A reference
2. $\mathrm{Xu}$ Bowen, Green Residential Household Satisfaction Evaluation Study[D]. Yunnan University of Finance and Economics, 2020

3. Xu Shengqi, Design Strategy Research based on the Green Building Evaluation Standard[D]. China Mining University, 2017

4. Shen Danning, Study on the Impact of Subsidy Policy on urban Green Building DevelopmentAnalysis based on China's Municipal Panel Data[D]. Shanghai University of Finance and Economics, 2019

5. Youyou Xiong, Uta Krogmann,Gediminas Mainelis, Lisa A. Rodenburg, Clinton J. Andrews. Indoor air quality in green buildings: A case-study in a residential high-rise building in the northeastern United States[J] . Journal of Environmental Science and Health, Part A .2015(3) 